\title{
COMPARATIVE STUDY BETWEEN SOME DIFFERENT POTATO HARVESTING MACHINE IN SMALL HOLDINGS
}

\author{
${ }^{1}$ M.M. Morad, \\ ${ }^{1}$ M.M.A. Ali, \\ ${ }^{2}$ Hanan M. El-Shal and ${ }^{3}$ S. L.A. El-Gendy
}

\section{ABSTRACT}

Field experiments were carried out to compare between some different potato harvesting machines (agitator potato digger, elevator potato digger and chisel plow) and evaluate their performance under field conditions. Potato harvesting machines performance was conducted under four different soil moisture contents $(9,11,13$ and 16\%) and thee different digging depths (22, 27 and $32 \mathrm{~cm})$. Digging operation was carried out at four different forward speeds (1.3, 1.8, 2.5 and $3.0 \mathrm{~km} / \mathrm{h}$.). Harvesting performance was evaluated in terms of potato losses, productivity, harvesting efficiency, energy requirements and harvesting cost. The experimental results reveal that the use of both agitator digger and elevator potato digger maximize harvesting efficiency and minimize losses and cost comparing with chisel plow under the following conditions: The suitable digging depth to dig all potato tubers is $32 \mathrm{~cm}$., the optimum soil moisture content suitable for digging potato is $13 \%$, the proper forward speed for operating potato diggers is $2.5 \mathrm{~km} / \mathrm{h}$.

Keywords: Agitator, digger, elevator digger, energy requirements ,harvesting efficiency

\section{INTRODUCTION}

$\mathrm{P}$ otato (Solanum tuberosum L.) popularly known as 'The king of vegetables, has emerged as fourth most important food crop in Egypt after rice, wheat and maize. Egyptian vegetables basket is incomplete without Potato because the dry matter, edible energy and edible protein content of potato makes it nutritionally superior vegetable as well as staple food not only in Egypt but also all over the world.

\footnotetext{
${ }^{1}$ Professor,Agric. Eng. Dept., Fac. of Agric., Zagazig Univ., Egypt ${ }^{2}$ Lecturer, Agric. Eng. Dept., Fac. of Agric., Zagazig Univ., Egypt.

${ }^{3}$ Postgraduate student, Agric. Eng. Dept., Fac.of Agric., Zagazig Univ., Egypt.
} 
The cultivated area in Egypt was about 330.000 fed to produce about 3.66 million ton/year distributed on the summer, Nile and winter seasons. The production year 2013 reached to 4.76 million tons (Ministry of Agric. Static., 2009, 2013).Harvesting is one of the most critical operations for potato production. Potato tubers are grown below the surface of the ground. Therefore, it requires specially designed machines to dig and separate them from the soil. Recently, some progress towards fully mechanized of potato harvesting have been occurred.The mechanical potato harvester performs the following operations, in sequence: a) Digging (b) Separation of loose soil, small clods and stones (c) Removing of the vines and weeds (d) Partial separation of the tubers from similar sized stones and clods. Potato is easily cut and cracked or skinned during the separation process; therefore the separation of potato from soil, similar size stones and clods is a major problem. Younis (1987) tested one row potato digger mounted on $51.5 \mathrm{~kW}(70 \mathrm{hp})$ tractor in sandy soil at different digging depths and forward speeds. He found that the total losses such as skinned potato and damage by the lifting operation were about $3 \%$ of the total yield compared with $8-14 \%$ for conventional harvesting (Baladi plow). Amin (1990) developed potato harvester having field capacity of $0.31 \mathrm{fed} / \mathrm{h}$ and field efficiency of $91.32 \%$ at forward speed of $2.1 \mathrm{~km} / \mathrm{h}$. Harvesting potato tubers using the developed harvester costed 16.47 L.E/fed, while the traditional methods costed 80 L.E/fed. Mady (1999) indicated that the increasing of digging depth and the decreasing of forward speed reduced the percentage of un-lifted roots, bruised roots and cut roots and increased the percentage of lifted roots and undamaged roots. The lowest values of unlifted roots were $3.0 \%$, bruised roots of $5.1 \%$, cut roots of $4.0 \%$ lifted roots of $97 \%$, undamaged roots of $90.9 \%$ and digging cost of 44.65 (LE/ton) were obtained at the digging depth of $40 \mathrm{~cm}$ and forward speed of $1.5 \mathrm{~km} / \mathrm{h}$. He also found that the lowest and highest energy requirements of 66.43 and $187.9 \mathrm{~kW} . \mathrm{h} . / \mathrm{fed}$ and the highest and lowest values of cost of 245.28 and 44.65 L.E/ton were obtained at digging depths of 25 and $40 \mathrm{~cm}$ and forward speeds of 3.6 and $1.5 \mathrm{~km} / \mathrm{h}$., respectively. Afify and Mechail (2000) developed and constructed a simple potato harvester. They found that the optimum forward speed for digging was $4.49 \mathrm{~km} / \mathrm{hto}$ increase the percentage of raised potato to $96.86 \%$, reduce the skin, and cut damage to $1.11 \%$ and 
missing tubers to $3.14 \%$. They reported that using a box-picker reducing the digging cost to 20\%. Abdel-Aal et al. (2002) modified a potato harvester to be suited for Egyptian farms. The optimum engineering parameters for the modified harvester were forward speed of $2.3 \mathrm{~km} / \mathrm{h}$., digger tilt angle of $14^{\circ}$, distance between the blade and elevator chain of 5 $\mathrm{cm}$, chain speed of $2.41 \mathrm{~m} / \mathrm{s}$ riddle speed of $11.16 \mathrm{~m} / \mathrm{s}$ and riddle inclination of $7^{\circ}$. They achieved the highest undamaged, lowest damaged and losses tubers $87.4 \%, 1.98$ and $10.62 \%$, respectively under the optimum engineering parameters for the modified harvester. Abdel Maksoud et al. (2004) developed a potato digger for harvesting and gathering potato. They recommended that the forward speed was about $2.4 \mathrm{~km} / \mathrm{h}$., penetration angle of $14^{\circ}$, sieve slope of $8^{\circ}$ and operating speed of $1.2 \mathrm{~m} / \mathrm{sec}$., to achieve the highest undamaged with the lowest damage and buried potato. Younis et al. (2006) developed and tested a potato digger at four levels of forward speed $(0.9,1.5,1.9$ and $3.2 \mathrm{~km} / \mathrm{h}$.), four levels of vibrating amplitude (3, 5, 6 and $10 \mathrm{~mm}$ ) and five levels of vibrating frequency $(400,600,800,1000$ and $1200 \mathrm{rpm})$. They found that the developed digger succeed to operate with lower power tractors thus the harvesting cost was reduced by $28.5 \%$. Ibrahim et al. (2008) developed a multi-purpose digger for harvesting root crops (potato and peanut). The developed digger was tested at thee levels of forward speed and thee different tilt angles. From the obtained results, the proper conditions to operate the developed digger were $22 \mathrm{~cm}$ harvesting depth, $2.6 \mathrm{~km} / \mathrm{h}$., forward speed and $18^{\circ}$ tilt angle for potato crop. The cost of harvesting using the digger was 91.55 L.E/fed. Tawfik and Abdallah (2012) fabricated a prototype of potato digger to suit small holdings, they revealed that the proper operation for the prototype potato digger are forward speed of $2.3 \mathrm{~km} / \mathrm{h}$., rake angle of $14^{\circ}$ and digging depth of $30 \mathrm{~cm}$ Ali (2013) manufactured a simplified potato digger and evaluated its performance under laboratory and field conditions. The suitable digging depth to dig all potato tubers is $27, \mathrm{~cm}$ the optimum soil moisture content suitable for digging potato is $11 \%$ (dry base), the proper forward speed for operating the manufactured potato digger is $2.2 \mathrm{~km} / \mathrm{h}$. Although several methods of separation have been proposed, none have been wholly successful without excessive operational cost and potato tubers damage. 
Therefore, the objectives of the present study are:

1.Compare the performance of three different potato harvesting machines.

2.Optimize some different operating parameters affecting the performance of potato harvesting machines.

3.Evaluate the performance of potato harvesting machines from the economic point of view.

\section{MATERIALS AND METHODS}

The experiments were carried out during 2013 at Shabab project farm, AlIsmailia Governorate. The mechanical analysis of the experimental soil was classified as a sandy soil as shown in Table (1).The experimental area was planted mechanically via belt potato planter (Stractural) using Diamant potato variety, that belongs to the medium late maturing varieties that take about (115-120) days to mature. Field experiments were planted with tuber rate of $1300 \mathrm{~kg} / \mathrm{fed}$., $70 \mathrm{~cm}$ row spacing, $20 \mathrm{~cm}$ planting depth and about $30 \mathrm{~cm}$ between hills in the same row.

Table (1): Mechanical analysis of the experimental soil Soil components

\begin{tabular}{|c|c|c|c|}
\hline $\begin{array}{l}\text { Clay } \\
(\%)\end{array}$ & Silt (\%) & Sand $(\%)$ & Soil type \\
\hline 5.80 & 4.38 & 89.82 & Sandy soil \\
\hline
\end{tabular}

A-Materials

\section{1-Potato specifications}

Average dimensions of potato tubers used in the experiments are as follows:

Length $(\mathrm{L})=93 \mathrm{~mm}$, Width $(\mathrm{W})=59 \mathrm{~mm}$ and thickness $(\mathrm{T})=53 \mathrm{~mm}$

\section{2-Equipment specifications}

Specifications of equipment which used in the present study are as follow:

\section{-Tractor}

A 4-wheel drive tractor (FIAT model 115-90DT) of the standard type $115 \mathrm{hp}(84.6 \mathrm{~kW})$ was used as a power source for operating the different potato harvesting machines.

\section{-Elevator digger}

Fig.(1) depicts the elevator digger that used for harvesting potato in the present study. Specifications of the elevator digger are shown in Table(2). 


\section{- Agitator digger}

Fig.(2) depicts the agitator digger that used for harvesting potato in the present study Specifications of the agitator digger are shown in Table (2).

\section{- Chisel plow}

A local mounted chisel plow was used for harvesting potato with 7 shares corresponding to $175 \mathrm{~cm}$ working width, plow mass is $250 \mathrm{~kg}$.

\section{$\underline{B \text {-Methods }}$}

The field experiments were carried out to evaluate the performance of thee different potato harvesting machines. The experimental area was about 12 feddans divided into four equal plots ( 3 feddans each) with dimensions of $(50 \times 252) \mathrm{m}$ with average four different soil moisture contents of 9,11, 13 and $16 \%(\mathrm{db})$. Each plot was divided into thee equal sub- plots (one feddan each) with dimensions of $(50 \times 84) \mathrm{m}$. In each subplot, one of the following potato harvesting machines was used:

- Potato elevator digger

- Potato agitator digger

- Chisel plow

Each sub-plot was divided into thee areas $(50 \times 28 \mathrm{~m})$ for thee different harvesting depths of 22,27 and $32 \mathrm{~cm}$. Each area was divided into four equal areas slices of $(50 \times 7 \mathrm{~m})$ to operate potato harvesting machines under four average different forward speeds of 1.3, 1.8, 2.5 and $3.0 \mathrm{~km} / \mathrm{h}$.

All experiments were carried out under recommended share angle of $14^{\circ}$ and chain speed of $10.4 \mathrm{rpm}(1.25 \mathrm{~m} / \mathrm{s})$. The vines of the potato were removed (killed) ten days before harvesting with chemical spraying.

Soil moisture content was determined on dry basis with the oven method at $105^{\circ} \mathrm{C}$ for 24 hours. Mechanical analysis and soil moisture contents were done in laboratory of Agriculture College, Zagazig University.

\section{-Measurements}

Evaluation of potato harvesting machines was carried out taking into consideration the following indicators:

\section{-Field capacity and field efficiency:}

Field efficiency (F.E) is the ratio of actual field capacity to theoretical field capacity expressed as follows:

$$
\text { Field efficiency }(\text { F.E })=\frac{\text { A. F.C }}{\text { T.F.C }} \times 100
$$

\section{Where:}


A.F.C: Actual field capacity, fed/h.

T.F.C: Theoretical field capacity, fed/h.

The theoretical field capacity was calculated by using the following relationship:

Theoretical field capacity (T.F.C $)=\frac{\mathrm{W} \times \mathrm{S}}{4.2} \quad$,fed./h.

\section{Where:}

$\mathrm{W}$ : Working width of potato harvesting machine, $\mathrm{m}$.

$\mathrm{S}$ : Average working forward speed, $\mathrm{km} / \mathrm{h}$.

$$
\text { Actual field capacity(A.F.C) }=\frac{1}{T_{a}} \quad \text {, fed./h. }
$$

\section{Where:}

Ta: Total actual time consumed to dig one feddan, $\mathrm{Ta}=\mathrm{T} 1+\mathrm{T} 2+\mathrm{T} 3$, T1: Digging time,h

T2: Turning tim,h.

T3: Adjustment time,h.

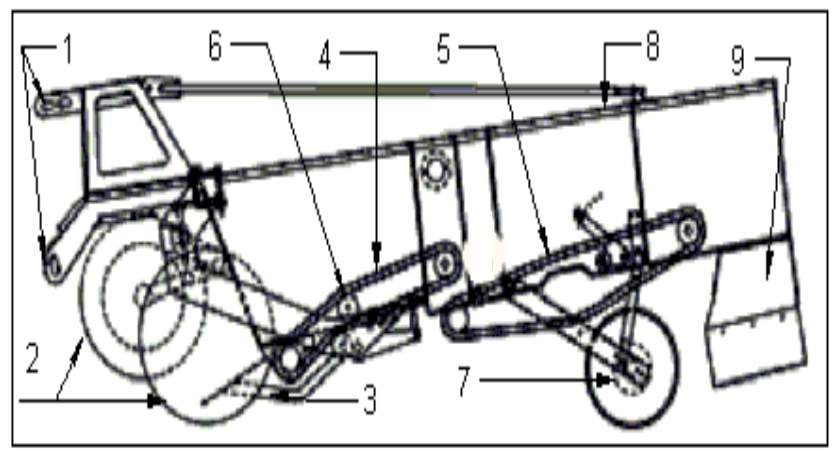

\begin{tabular}{cl}
\hline $\begin{array}{c}\text { Part } \\
\text { No. }\end{array}$ & \multicolumn{1}{c}{ Name } \\
\hline 1 & Linkage attachment point \\
2 & Disc coulters \\
3 & Share blade with 3 legs \\
4 & Front web \\
5 & Rear web \\
6 & Rollers \\
7 & wheel \\
8 & Frame \\
9 & Gather \\
\hline
\end{tabular}

Fig.(1): Elevator digger

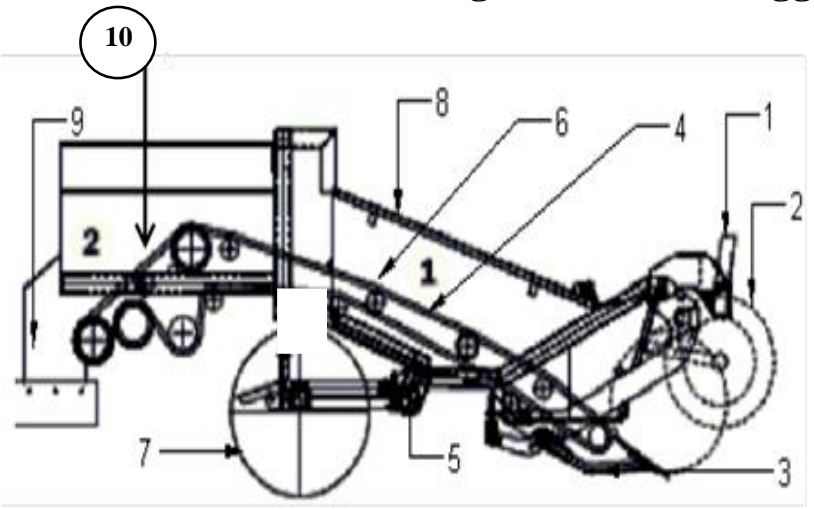

\begin{tabular}{cl}
\hline $\begin{array}{c}\text { Part } \\
\text { No. }\end{array}$ & \multicolumn{1}{c}{ Name } \\
\hline 1 & Linkage attachment point \\
2 & Disc coulters \\
3 & Share blade with 3 legs \\
4 & web \\
5 & Driven rotary agitator in \\
6 & Rollers \\
7 & wheel \\
0 & Frame \\
& Gather \\
10 & Italic end of web \\
\hline
\end{tabular}

Fig.(2): Agitator digger 


\section{Table(2) :The technical specifications of the potato diggers.}

\begin{tabular}{|c|c|c|}
\hline Item & Elevator digger & Agitator digger \\
\hline Source/Model & Germany / Grimme GVR 1700 & Germany /Grimme RL 1700 \\
\hline Type & semi-mounted & semi-mounted \\
\hline \multicolumn{3}{|l|}{ Dimensions: } \\
\hline Length, m & 3.80 & 4.6 \\
\hline Width, m & 2.05 & 2.28 \\
\hline Height, $m$ & 1.20 & 1.65 \\
\hline Mass, $\mathrm{kg}$ & 1500 & With haulm web: 2350 \\
\hline Tires & $5.00-8$ & $10.0 / 75-15$ \\
\hline Row width & $75-90 \mathrm{~cm}$ & $75-90 \mathrm{~cm}$ \\
\hline Number of rows & Two & Two \\
\hline Intake & 4 disc coulters (spring loaded and pulled) & $\begin{array}{l}4 \text { disc coulters (spring loaded and } \\
\text { pulled) }\end{array}$ \\
\hline Share type & Share blade with 3 legs & Share blade with 3 legs \\
\hline Share depth control & With Diablo rollers & With diablo rollers \\
\hline Main webs & $\begin{array}{l}1^{\text {st }} \text { main web (front) } 1.64 \mathrm{~m} \text { wide, } \\
1.40 \mathrm{~m} \text { long, } 40 \mathrm{~mm} \text { pitch } \\
2^{\text {nd }} \text { web (rear) } 1.64 \mathrm{~m} \text { wide, } 1.10 \mathrm{~m} \text { long, } 40 \mathrm{~mm} \text { pitch }\end{array}$ & $\begin{array}{l}\text { main web } 1.64 \mathrm{~m} \text { wide, } 3.40 \mathrm{~m} \\
\text { long, } 40 \mathrm{~mm} \text { pitch }\end{array}$ \\
\hline Agitator & Driven rotary agitator in $2^{\text {nd }}$ main web & $\begin{array}{l}\text { Driven rotary agitator in } 1^{\text {st }} \text { main } \\
\text { web Option: electrically adjustable } \\
\text { agitator Option: two rotary } \\
\text { agitators in } 1^{\text {st }} \text { main web }\end{array}$ \\
\hline Power requirement & $55 \mathrm{hp} \mathrm{(40)} \mathrm{kW}$ & $47.6 \mathrm{hp}(35) \mathrm{kW}$ \\
\hline Potato discharge & $\begin{array}{l}\text { Centre discharge at the rear of the machine Option: } \\
\text { hydraulically driven cross conveyor to one side }\end{array}$ & $\begin{array}{l}\text { Centre discharge at the rear of the } \\
\text { machine Option: hydraulically } \\
\text { driven cross conveyor to one side }\end{array}$ \\
\hline
\end{tabular}

\section{-Raised tubers}

The raised tubers $\left(\mathrm{R}_{\mathrm{t}}\right)$ in $\mathrm{Mg}$ /feddan was determined by massing the tuber (Mr) kg raised by the digger over the soil surface collected from a length to (10) $\mathrm{m}$ by using the following equation (Arfa, 2007):

$$
\mathrm{R}_{\mathrm{t}}=\frac{4200 \times \mathrm{Mr}}{(1.8 \times 10) \times 1000}, \mathrm{Mg} / \mathrm{fed} \text {. }
$$

\section{Where:}

$\mathrm{R}_{\mathrm{t}}$ : Raised tubers, $\mathrm{Mg} / \mathrm{fed}$.

Mr: Mass of the raised tubers, $\mathrm{kg}$

$(1.8 \times 10)$ : Area of unit it's length $(10) \mathrm{m}$ and the width equal $1.8 \mathrm{~m}$.

\section{-Buried tubers}

The buried tubers determined by massing the buried tuber by manual digging form the experimental area of $(1.8 \times 100) \mathrm{m}^{2}$ using the following equation: 


$$
\mathrm{Bt}=\frac{4200 \times \mathrm{Mb}}{(1.8 \times 10) \times 1000}, \mathrm{Mg} / \mathrm{fed}
$$

\section{Where:}

Bt: buried tubers, $\mathrm{Mg} / \mathrm{fed}$.

$\mathrm{Mb}$ : Mass of buried tubers, $\mathrm{kg}$

\section{- Damaged and undamaged tubers}

Random samples of tubers were collected and weighted for each treatment, each sample was divided into two portions, the damaged $\left(D_{t}\right)$ and un-damaged tubers $\left(\mathrm{U}_{\mathrm{t}} \mathrm{D}_{\mathrm{t}}\right)$, the mass of damaged tubers is $\left(\mathrm{m}_{1}\right)$ and the mass of un-damaged tubers is $\left(\mathrm{m}_{2}\right)$.

\section{- Total crop losses}

Total crop losses can be determined using the following equation:

Total crop losses $(\mathrm{Mg} / \mathrm{fed})=$ Buried tubers + Damaged tubers

\section{- Harvesting efficiency}

Harvesting efficiency is calculated by using the following equation:

\section{Where:}

$$
\eta_{\mathrm{H}}=\frac{\mathrm{R}_{\mathrm{t}}-\mathrm{D}_{\mathrm{t}}}{\mathrm{M}_{\mathrm{t}}} \times 100, \%
$$

$\mathrm{R}_{\mathrm{t}}$ : Mass of tubers lifted on surface, $\mathrm{kg}$

$\mathrm{D}_{\mathrm{t}}$ : Mass of damaged tubers, $\mathrm{kg}$

$\mathrm{M}_{\mathrm{t}}$ : Mass of total tubers in experimental area, $\mathrm{kg}$

\section{- Fuel consumption}

During the harvesting operation, fuel consumption was determined by measuring the required fuel to refill the fuel tank after the working periods by means of graduated glass cylinder it was calculated by using the following equation:

$$
\mathrm{Fc}=\frac{\mathrm{Vf}}{\mathrm{T}} \times 3.6 \quad, \mathrm{~L} / \mathrm{h} .
$$

\section{Where:}

Fc: Fuel consumption

Vf: Volume of consumed fuel, $\mathrm{cm}^{3}$

T: Time of digging, $\mathrm{s}$

\section{- Required power}

Required power was estimated from the fuel consumed during the harvesting operation using the following formula (Barger et al., 1963) 
$\mathrm{p}=\mathrm{F}_{\mathrm{C}} \times \frac{1}{60 \times 60} \times \rho_{\mathrm{f}} \times$ L.C. $\mathrm{V} \times 427 \times \eta_{\mathrm{th}} \times \eta_{\mathrm{m}} \times \frac{1}{75} \times \frac{1}{1.36}, \quad \mathrm{~kW}$

\section{Where:}

Fc: Fuel consumption, L/h.

$\rho_{\text {f: }}$ Density of fuel, $\mathrm{kg} / 1$ (for diesel fuel $0.85 \mathrm{~kg} / \mathrm{L}$

$\eta_{\text {th }}$ : Thermal efficiency $\approx 40 \%$ for diesel engine

$\eta_{\mathrm{m}}$ : Mechanical efficiency of the engine (80-85\%)

L.C.V: Lower Calorific value of fuel (10000-11000) kcal/kg

427 : Thermo mechanical equivalent $\mathrm{J} / \mathrm{kcal}$

\section{- Energy Requirements}

Estimation of the energy required for operating the harvesting machines was carried out using the following formula:

Energy requirements $=\frac{\text { Required power }(}{\text { Actual field capacity }(\mathrm{fad} / \mathrm{h} .)}, \mathrm{kW} . \mathrm{h} . / \mathrm{fed}$.

\section{- Machine hourly cost}

Machine and tractor hourly cost was determined by using the following equation (Awady, 1978):

$$
\mathrm{C}=\mathrm{p} / \mathrm{h}[1 / \mathrm{e}+\mathrm{i} / 2+\mathrm{t}+\mathrm{r}]+(1.2 \mathrm{~W} \times \mathrm{f} \times \mathrm{s})+\frac{\mathrm{M}}{144}
$$

\section{Where:}

C: Hourly cost, LE/h.

P: price of machine, LE

h: Yearly working hour, h./year

e: Life expectancy of equipment in year .

i: Interest rate, $\%$

$\mathrm{t}$ : Taxes and over heads ,\%

r: Repairs ratio of total investment $\%$

1.2: A factor including reasonable estimation of the oil consumption in addition to fuel.

$\mathrm{W}$ : Power of engine, $\mathrm{kW}$

F: Specific fuel consumption, L/hp.h.

S: Price of fuel per liter, LE/L

M: Labor wage rate per month, LE/month

144: Monthly average of working hour's

\section{-Operating cost}

The operating cost was determined from the following formula: 
Operating cost $=\frac{\text { Machine cost, L.E/h. }}{\text { Actual field capacity, fed./h. }}$, LE/fed.

\section{Product losses cost}

Product losses cost was determined from the following formula:

Product losses cost $=\mathrm{L}_{1}\left(\mathrm{P}_{0}-\mathrm{P}_{1}\right)+\mathrm{L}_{2} \mathrm{P}_{0} \mathrm{LE} / \mathrm{fed}$.

\section{Where:}

$\mathrm{L}_{1}$ : Damage tubers, $\mathrm{kg} / \mathrm{fed}$

$\mathrm{L}_{2}$ : Buried tuber, $\mathrm{kg} / \mathrm{fed}$.

$\mathrm{P}_{0}$ : The price of one $\mathrm{kg}$ of intact potato tuber. L.E $/ \mathrm{kg}$,

$\mathrm{P}_{1}$ : The price of one $\mathrm{kg}$ of damaged potato tuber, L.E/kg.

\section{-Criterion Cost}

Criterion cost (C) can be calculated using the following equation (Awady et al., 1982).

$\mathrm{C}=$ operating cost + product losses cost, L.E/fed.

\section{RESULTS AND DISCUSSION}

\section{1- Effect of Harvesting Machine Operating Parameters on Field} Capacity and Field Efficiency:

Concerning the effect of machine forward speed on field capacity and field efficiency, the obtained results in Fig.(3) showed a remarkable drop in the field efficiency with a consequent sharp rise in actual field capacity due to increasing the forward speed. Results show that, increasing forward speed from 1.3 to $3.0 \mathrm{~km} / \mathrm{h}$, leads to increase the actual field capacity values from 0.49 to 1.00 , from 0.48 to 0.95 and from 0.50 to 1.04 $\mathrm{fed} / \mathrm{h}$, for agitator digger, elevator digger and chisel plow, respectively at soil moisture content of $13 \%$ and harvesting depth of $32 \mathrm{~cm}$. On the other hand, increasing forward speed from 1.3 to $3.0 \mathrm{~km} / \mathrm{h}$, leads to decrease field efficiency values from 89.06 to $77.92 \%$, from 87.1 to $74.53 \%$ and from 90.81 to $81.08 \%$, for agitator digger, elevator digger and chisel plow, respectively under the same previous conditions. The major reason for the reduction in field efficiency by increasing forward speed is due to the low value of the theoretical time. Regarding to the effect of soil moisture content on field capacity and field efficiency, the obtained results in Fig.(3) showed that, increasing soil moisture content from 9 to $16 \%$ leads to decrease the actual field capacity values from 0.81 to 0.77 , from 0.78 to 0.74 and from 0.84 to $0.807 \mathrm{fed} . / \mathrm{h}$, for agitator digger, elevator digger and chisel plow, respectively at harvesting machine forward speed of $2.5 \mathrm{~km} / \mathrm{h}$., and harvesting depth of $32 \mathrm{~cm}$. 


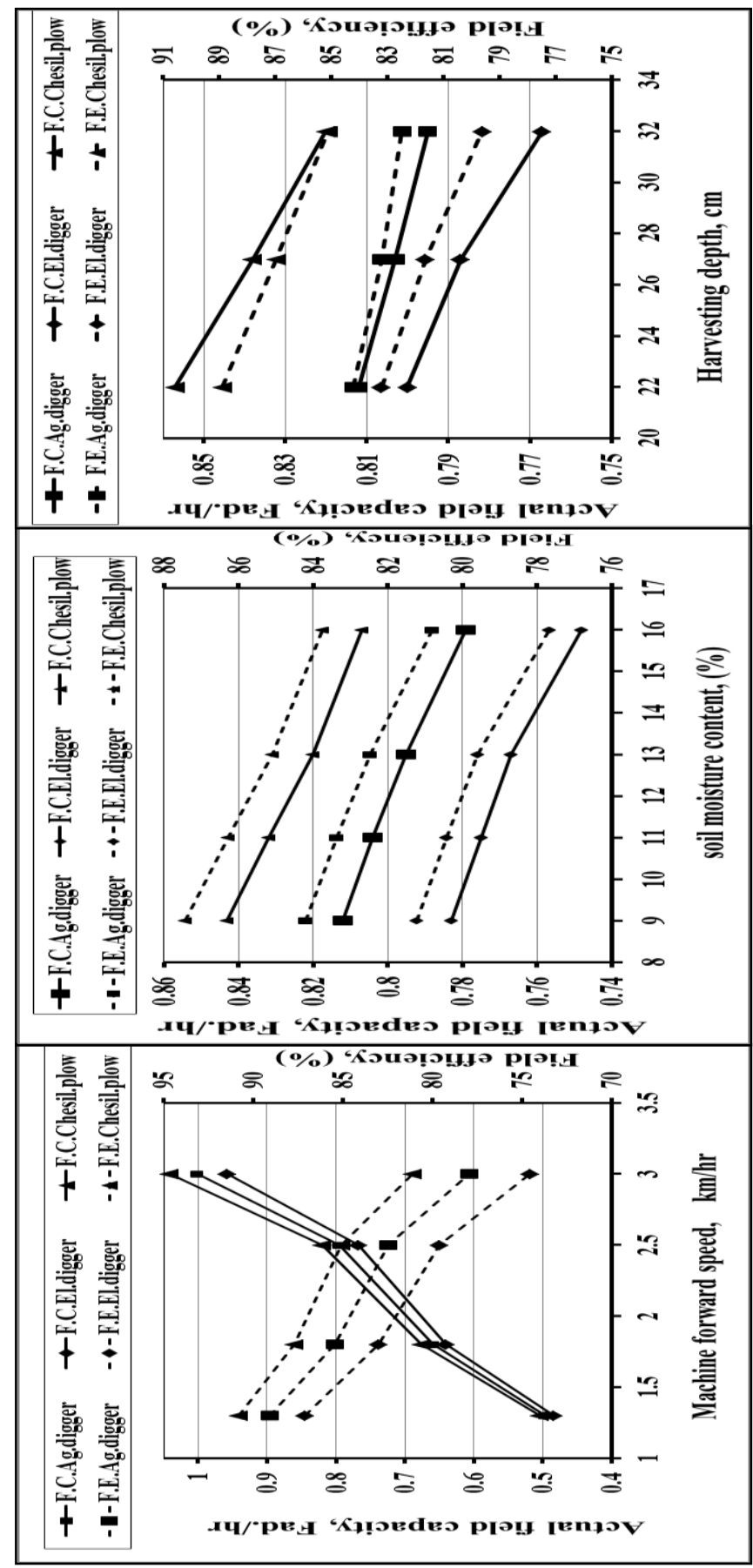

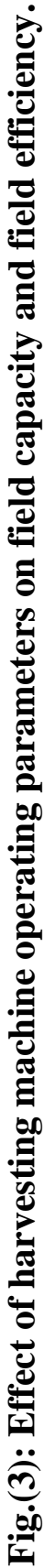


Also increasing soil moisture content from 9 to $16 \%$ leads to decrease field efficiency values from 84.21 to 80.8 , from 81.21 to 77.66 and from 87.43 to $83.76 \%$ for agitator digger, elevator digger and chisel plow respectively under the same previous conditions.

Regarding to the effect of harvesting depth on field capacity and field efficiency, Fig.(3) shows that, increasing harvesting depth from 22 to 32 $\mathrm{cm}$ leads to decrease the actual field capacity values from 0.81 to 0.79 , from 0.80 to 0.76 and from 0.85 to 0.82 fed./h., for agitator digger, elevator digger and chisel plow, respectively at harvesting machine forward speed of $2.5 \mathrm{~km} / \mathrm{h}$., and soil moisture content of $13 \%$. Also, increasing harvesting depth from 22 to $32 \mathrm{~cm}$ leads to decrease field efficiency values from 84.21 to $82.47 \%$, from 83.21 to $79.60 \%$ and from 88.88 to $85.10 \%$ for agitator digger, elevator digger and chisel plow, respectively under the same previous conditions. From this point of view, it was noticed that the highest field capacity was obtained by using chisel plow for harvesting potato at forward speed $3.0 \mathrm{~km} / \mathrm{h}$., and harvesting depth of $22 \mathrm{~cm}$ in soil moisture content of $9 \%$ meanwhile, the lowest value was obtained by using elevator digger at forward speed $1.3 \mathrm{~km} / \mathrm{h}$., and harvesting depth of $32 \mathrm{~cm}$ in soil moisture content of $16 \%$. At the same time the highest value of field efficiency was noticed with the use of chisel plow for harvesting potato at forward speed $1.3 \mathrm{~km} / \mathrm{h}$, harvesting depth of $22 \mathrm{~cm}$ and soil moisture content of $9 \%$ while, the lowest value was obtained by using elevator digger at forward speed $3.0 \mathrm{~km} / \mathrm{h}$, harvesting depth of $32 \mathrm{~cm}$ and soil moisture content of $16 \%$.

\section{2- Effect of Harvesting Machine Operating Parameters on Potato} Tuber Losses:

\section{-Buried tubers}

The obtained results in Fig.(4) shows that, the buried tubers were more pronounced as the forward speed increased at any harvesting depth up to $2.5 \mathrm{~km} / \mathrm{h}$. The obtained data showed that increasing forward speed from 1.3 to $2.5 \mathrm{~km} / \mathrm{h}$, decreased the buried tubers from 2.38 to 1.87 , from 1.38 to 1.03 and from 0.38 to $0.19 \mathrm{Mg} / \mathrm{fed}$ at harvesting depth of 22,27 and $32 \mathrm{~cm}$ respectively, using agitator digger, while it decreased from 2.8 to 2.20 , from1.62 to 1.21 and from 0.45 to $0.23 \mathrm{Mg} / \mathrm{fed}$ at the mentioned depths using elevator digger and from 4.19 to 4.08 , from 3.68 to 3.47 and from 2.48 to 1.79 $\mathrm{Mg} / \mathrm{fed}$ using chisel plow at soil moisture content of $13 \%$. Any further increase in forward speed more than 2.5 up to $3.0 \mathrm{~km} / \mathrm{h}$, the contrarily 
trend was noticed under the same previous conditions. The increase in buried tubers at high forward speeds may be due to the floating action of the digger blades that increased the circulating motion of soil on the blades consequently more potato tubers were left in the soil.The obtained results in Fig.(5) show that, increasing soil moisture content from 9 to $13 \%$, and harvesting depth from 22 to $32 \mathrm{~cm}$, decreased buried tubers from 2.0 to 0.19 , from 2.43 to 0.23 and from 4.16 to 1.79 for agitator digger, elevator digger and chisel plow, respectively at forward speed of $2.5 \mathrm{~km} / \mathrm{h}$. Any further increase in soil moisture content more than 13 up to $16 \%$, the contrarily was occurred under the mentioned previous conditions. The increase of buried tubers at high soil moisture content may be attributed to the cohesive nature of the soil slice which interfaced the digger blade, where cohesive soil slice keep potato tubers in the soil consequently increased buried tubers.

\section{-Damaged tubers}

The obtained results in Fig.(4) show that, the damaged tubers were more pronounced as the forward speed increased at any harvesting depth up to $3.0 \mathrm{~km} / \mathrm{h}$. The obtained data showed that, increasing forward speed from 1.3 to $3.0 \mathrm{~km} / \mathrm{h}$, increased the damaged tubers from 2.780 to 3.069 , from 1.567 to 1.743 and from 0.267 to $0.406 \mathrm{Mg} /$ fed at harvesting depth of 22,27 and $32 \mathrm{~cm}$ respectively, using agitator digger, while it increased from 3.068 to 3.302, from 1.685 to 1.890 and from 0.303 to $0.467 \mathrm{Mg} / \mathrm{fed}$, at the mentioned depths using elevator digger and from 3.460 to 3.721 , from 1.898 to 2.128 and from 0.339 to $0.522 \mathrm{Mg} / \mathrm{fed}$, using chisel plow under soil moisture content of $13 \%$. The increase of damaged tubers by increasing forward speed is due to the floating action of the blade and increasing the circulation motion of the soil on the blade which subjected potato tubers to more friction resulting in high damaged tubers. The highest damaged tubers at a low depth is due to breaking tubers by the share at potato tuber level, also the damaged tubers are greatly affected by soil moisture content as shown in Fig.(5). The obtained data indicated that, increasing soil moisture content from 9 to $13 \%$ and harvesting depths of 22 to $32 \mathrm{~cm}$, decreased damaged tubers from 3.05 to 0.32 , from 3.30 to 0.38 and from 3.71 to $0.43 \mathrm{Mg} / \mathrm{fed}$ for agitator digger, elevator digger and chisel plow, respectively at constant forward speed of $2.5 \mathrm{~km} / \mathrm{h}$. Any further increase in soil moisture content more than 13 up to $16 \%$, the damaged tubers increased under the same mentioned conditions. 

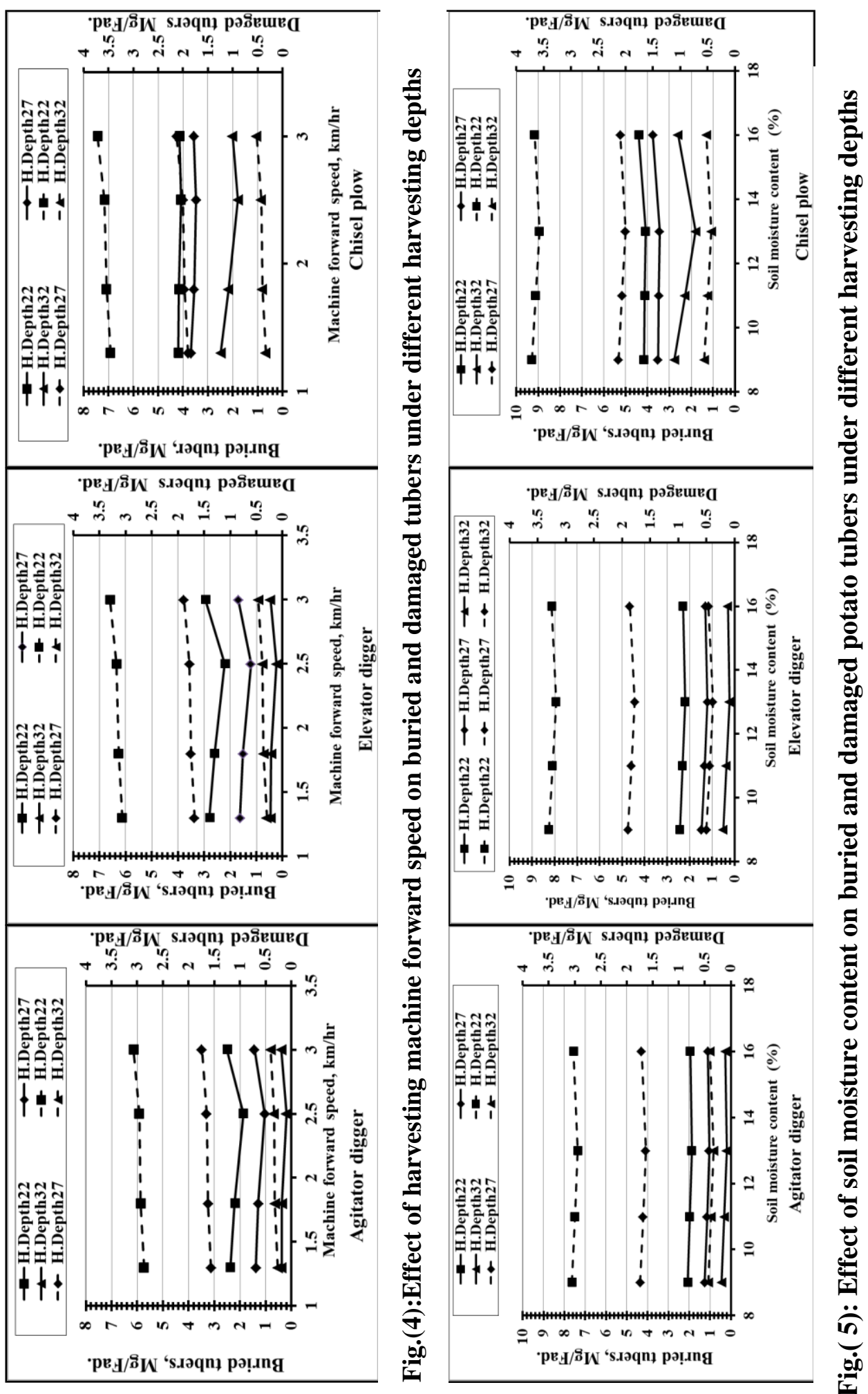


\section{-Total crop losses}

\section{-Total crop losses}

The obtained results in Fig.(6) showed that increasing forward speed from 1.3 to $2.5 \mathrm{~km} / \mathrm{h}$, decreased total losses from 5.25 to 4.83 , from 2.950 to 2.67 and from 0.65 to $0.56 \mathrm{Mg} / \mathrm{fed}$ at harvesting depths from 22 to $32 \mathrm{~cm}$ respectively using agitator digger, while it decreased from 5.86 to 5.37 , from 3.31 to 2.99 and from 0.75 to $0.61 \mathrm{Mg} / \mathrm{fed}$ at the mentioned depths using elevator digger and from 7.70 to 6.65 , from 5.56 to 5.44 and from 2.582 to 2.22 $\mathrm{Mg} / \mathrm{fed}$ using chisel plow, under soil moisture content of $13 \%$. Any further increase in forward speed more than 2.5 up to $3.0 \mathrm{~km} / \mathrm{h}$, the total losses increased under the same previous conditions. The increase in total losses tubers at high forward speeds is due to the increase in both buried and damaged tubers. The obtained results in Fig.(7) showed that increasing soil moisture content from 9 to $13 \%$, the total losses decreased from 5.13 to 4.83 , from 2.99 to 2.67 and from 0.87 to $0.53 \mathrm{Mg} /$ fed at harvesting depths of 22, 27 and $32 \mathrm{~cm}$ respectively, using agitator digger; while the total losses decrease from 5.74 to 5.37, from 3.36 to 2.99 and from 1.01 to $0.61 \mathrm{Mg} / \mathrm{fed}$ at the depths of 22,27 and $32 \mathrm{~cm}$ respectively using elevator digger, but for the chisel plow the losses decreased from 8.05 to 6.65 , from 5.85 to 5.44 and from 3.32 to 2.22 at the mentioned depths under forward speed of $2.5 \mathrm{~km} / \mathrm{h}$. Any further increase in soil moisture content more than 13 up to $16 \%$, total losses increased under the mentioned previous conditions. The obtained data showed that the highest total losses of 8.25, 6.78 and $6.02 \mathrm{Mg} / \mathrm{fed}$ were recorded at forward speed of $3.0 \mathrm{~km} / \mathrm{h}$, soil moisture content of $9 \%$ and harvesting depth of $22 \mathrm{~cm}$ for chisel plow, elevator digger and agitator digger, respectively. While the lowest total losses tubers of 2.22, 0.61 and $0.53 \mathrm{Mg} /$ fed were recorded at forward speed of $2.5 \mathrm{~km} / \mathrm{h}$, soil moisture content of $13 \%$ and harvesting depth of $32 \mathrm{~cm}$ under the same mentioned machines respectively. The increase in total crop losses at high forward speed, low harvesting depth and high soil moisture content is due to the increase in both buried and damaged tubers.

\section{3- Effect of Harvesting Machine Operating Parameters on Raised Tubers and Harvesting Efficiency \\ - Raised tubers}

Fig.(8) showed that, increasing forward speed from 1.3 to $2.5 \mathrm{~km} / \mathrm{h}$., and 
the harvesting depths from 22 to $32 \mathrm{~cm}$, increased the raised tubers from 14.87 to19.25 ,from 13.65 to 17.66 , and from 10.77 to $14.49 \mathrm{Mg} / \mathrm{fed}$, for agitator digger; elevator digger and chisel plow, respectively at soil moisture content of $13 \%$. Any further increase in forward speed more than 2.5 up to $3.0 \mathrm{~km} / \mathrm{h}$, raised tubers decreased under the same operating conditions. Fig.(9) showed that, increase soil moisture content from 9 to $13 \%$, and harvesting depths from 22 to $32 \mathrm{~cm}$, increased raised tubers from 16.16 to 19.15 , from 14.82 to 17.66 and from 11.54 to 14.49 $\mathrm{Mg} /$ fed for agitator digger, elevator digger and chisel plow respectively. Any further increase in soil moisture content more than 13 up to $16 \%$, the raised tubers decreased under the same conditions. The decrease in raised tubers at soil moisture content less or more than $13 \%$ is attributed to the high catching force at lower soil moisture content and high elastic soil conditions at higher moisture content.

\section{- Harvesting efficiency}

Fig.(8) shows that, increasing forward speed from 1.3 to $2.5 \mathrm{~km} / \mathrm{h}$., and harvesting depths from 22 to $32 \mathrm{~cm}$, increased the harvesting efficiency from 69.57 to $97.24 \%$, from 64.32 to $96.54 \%$ and from 48.88 to $86.35 \%$ for agitator digger elevator digger and chisel plow, respectively at soil moisture content of $13 \%$. Any further increase in forward speed more than 2.5 up to $3.0 \mathrm{~km} / \mathrm{h}$., harvesting efficiency decreased under the same conditions. The increase in harvesting efficiency by increasing forward speed up to $2.5 \mathrm{~km} / \mathrm{h}$ was attributed to the increase in raised potato at that range of speeds. While the decrease in harvesting efficiency at speeds higher than 2.5 up to $3 \mathrm{~km} / \mathrm{h}$ was attributed to the decrease of the raised potatoes compared with the increase in buried potatoes. The obtained results in Fig.(9) show that, increasing soil moisture content from 9 to $13 \%$, and harvesting depths from 22 to $32 \mathrm{~cm}$, increased the harvesting efficiency from 71.79 to $97.243 \%$; from 66.75 to $96.54 \%$ and from 49.81 to $86.35 \%$ for the agitator digger, elevator digger and chisel plow respectively, but any further increase in soil moisture content more than 13 up to $16 \%$, harvesting efficiency decreased slightly under the same conditions. The obtained data showed that the highest values of harvesting efficiency of $97.24,96.54$ and $86.35 \%$ were recorded at forward speed of $2.5 \mathrm{~km} / \mathrm{h}$., soil moisture content of $13 \%$ and harvesting 

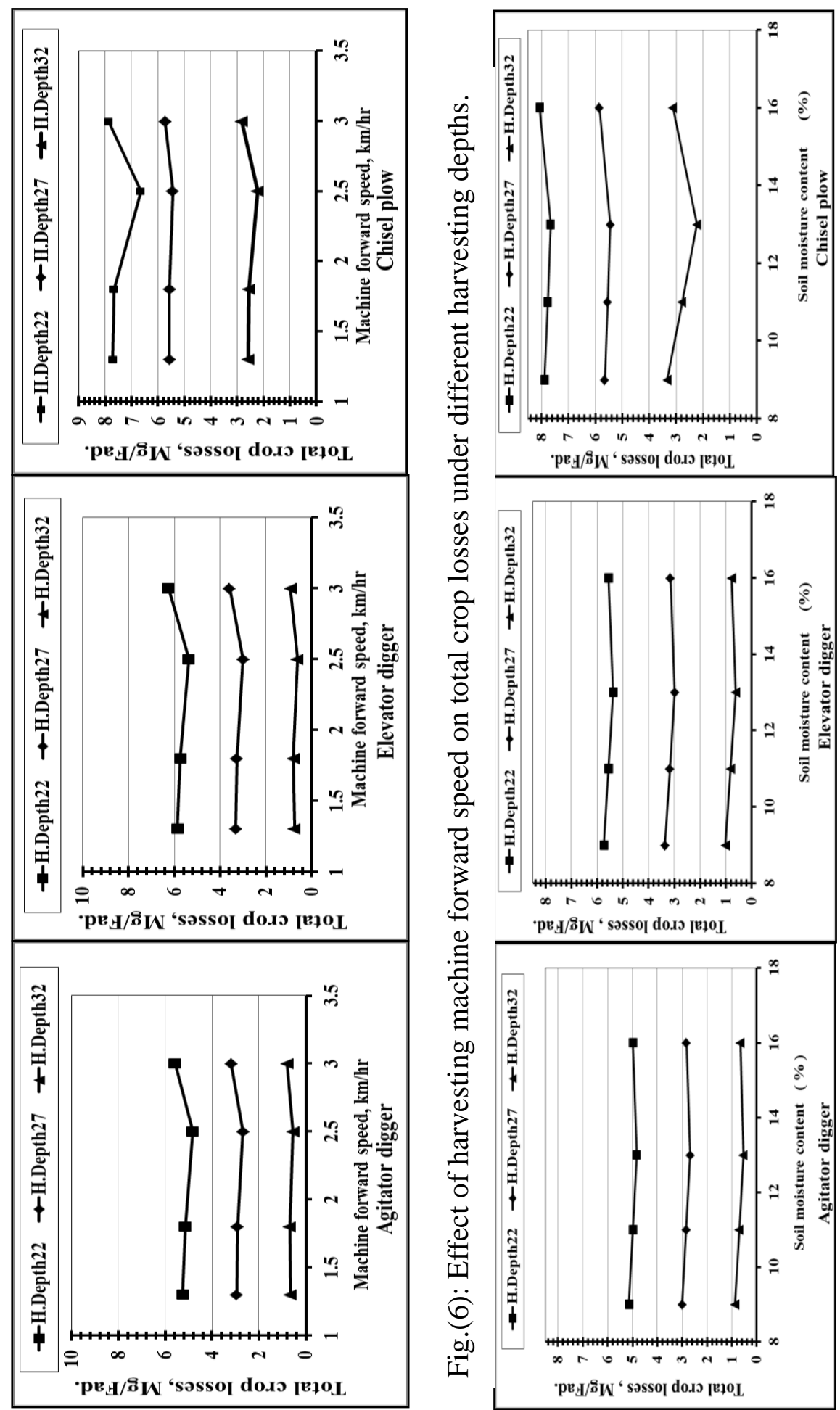

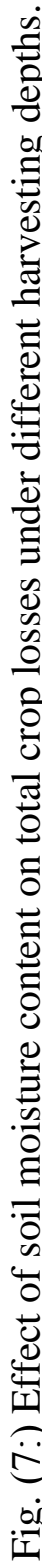



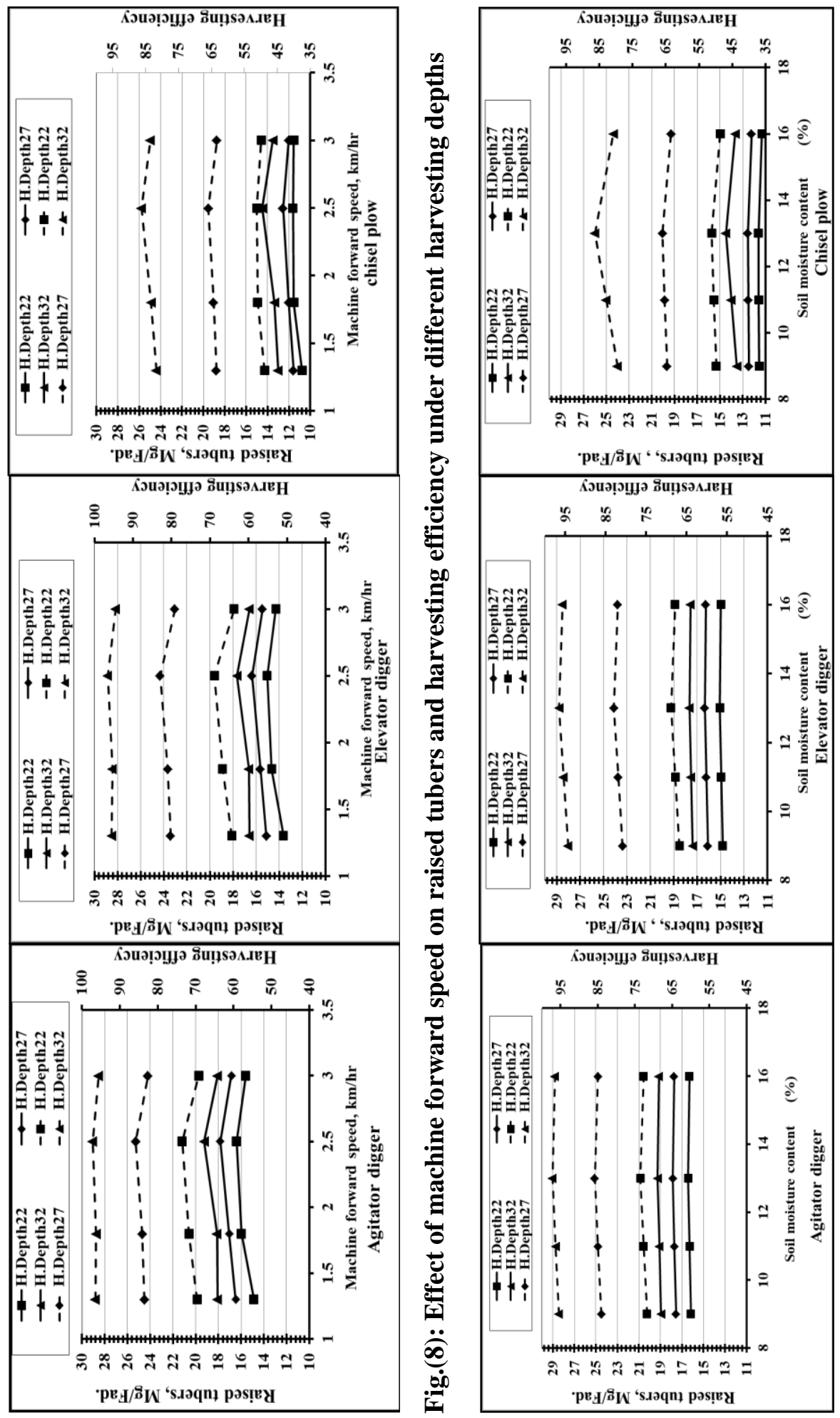

|气 
depth of $32 \mathrm{~cm}$ for agitator digger, elevator digger and chisel plow respectively. On the other hand, the lowest values of harvesting efficiency of $66.55,60.71$ and 46.18 were obtained at forward speed of $3.0 \mathrm{~km} / \mathrm{h}$., soil moisture content $9 \%$ and harvesting depth of $22 \mathrm{~cm}$ for agitator digger, elevator digger and chisel plow respectively.

\section{4- Effect of Harvesting Machine Operating Parameters on Power and Energy Requirements}

\section{-Required power}

The obtained results in Fig.(10) showed that, the increasing forward speed from 1.3 to $3.0 \mathrm{~km} / \mathrm{h}$ and the harvesting depth from 22 to $32 \mathrm{~cm}$, increased the required power from 22.99 to $31.05 \mathrm{~kW}$, from 27.71 to $36.39 \mathrm{~kW}$ and from 21.74 to $30.05 \mathrm{~kW}$ for the agitator digger, elevator digger and chisel plow respectively under soil moisture content of $13 \%$. Fig.(11) showed that increasing soil moisture content from 9 to $16 \%$ and the harvesting depths from 22 to $32 \mathrm{~cm}$, the required power increased from 25.13 to $32.20 \mathrm{~kW}$, from 29.99 to $37.918 \mathrm{~kW}$ and from 24.06 to $31.048 \mathrm{~kW}$ for agitator digger elevator digger and chisel plow respectively at forward speed of $2.5 \mathrm{~km} / \mathrm{h}$.

\section{-Energy requirements}

Fig.(10) shows that, increasing forward speed from 1.3 to $3.0 \mathrm{~km} / \mathrm{h}$., measured, decreased energy requirements from 45.2 to 25.5 , from 49.4 to 28.04 and from 54.24 to $30.99 \mathrm{~kW} . \mathrm{h} . / \mathrm{fed}$, at harvesting depths of 22,27 and $32 \mathrm{~cm}$ using agitator digger respectively, while the consumed energy decreased from 55.15 to 31.19 ,from 60.57 to 34.35 and from 66.45 to $37.97 \mathrm{~kW}$.h./fed using elevator digger under mentioned depths and from 41.87 to 23.67 , from 45.99 to 26.08 and from 50.45 to $28.82 \mathrm{~kW}$.h./fed using chisel plow under constant soil moisture content of $13 \%$. The decrease in energy requirements by increasing forward speed could be due to the high increase in field capacity compared with the increased in the required power. The decrease in energy requirements by increasing forward speed could be due to the high increase in field capacity compared with the increased in the required power. Fig.(11) shows that, increasing soil moisture content from 9 to $16 \%$ and harvesting depth from 22 to $32 \mathrm{~cm}$, increased energy requirements from 29.52 to $41.32 \mathrm{~kW} . \mathrm{h} . /$ fed, from 36.13 to $50.62 \mathrm{~kW}$.h/fed and from 27.45 to 38.436 
$\mathrm{kW} . \mathrm{h} / \mathrm{fed}$, for the agitator digger elevator digger and chisel plow respectively at forward speed of $2.5 \mathrm{~km} / \mathrm{h}$.

\section{5- Effect of the Harvesting Machine Operating Parameters on Criterion Cost}

Fig.(12) shows that increasing forward speed from 1.3 to $2.5 \mathrm{~km} / \mathrm{h}$, decreased criterion cost from 13082.6 to 11673.4 , from 7489.8 to 6523.4 and from 1907.1 to 1405.7 L.E/fed at harvesting depths of 22, 27 and 32 $\mathrm{cm}$ respectively using agitator digger, also the costs decreased from 14765.4 to 13106.0 , from 8484.3 to 7346.4 and from 2214.6 to 1626.5 L.E/fed using elevator digger at the mentioned depths, meanwhile the costs decreased from 19348.3 to 19142.2 , from 11919.6 to 11416.4 and from 7424.58 to 6297.64 L.E/fed using chisel plow for the three depths under soil moisture content of $13 \%$. Any further increase in forward speed more than 2.5 up to $3.0 \mathrm{~km} / \mathrm{h}$., criterion cost increased under the same previous conditions. The decrease in criterion cost in the speed range from 1.3 to $2.5 \mathrm{~km} / \mathrm{h}$ was attributed to the increased in field capacity, while the increase in criterion cost by increasing forward speed up to $3.0 \mathrm{~km} / \mathrm{h}$ is due to the increase in total losses cost. The obtained results in Fig.(13) showed that increasing soil moisture content from 9 to $13 \%$, decreased criterion cost from 12482.6 to 11673.4 , from 7372.6 to 6523.3 and from 2314.1 to 1405.7 L.E/fed at harvesting depths of 22, 27 and $32 \mathrm{~cm}$ respectively using agitator digger, also the costs decreased from 14058.7 to 13106 , from 8345.5 to 7346.4 and from 2695.2 to 1626.5 LE/fed using elevator digger at the mentioned depths, while the costs decreased from2 0291.6 to 19142.2 , from 12535.3 to 11416.4 and from 9365.68 to $6297.64 \mathrm{~L}$.E/fed using chisel plow at the three depths of 22,27 and $32 \mathrm{~cm}$ respectively under forward speed of $2.5 \mathrm{~km} / \mathrm{h}$. Any further increase in soil moisture content more than 13 up to $16 \%$, criterion cost increased under the mentioned previous conditions.

\section{CONCLUSION}

The recommendations of the present work can be summarized as follow:

1.The agitator potato digger followed by elevator potato digger are recommended to be used for harvesting potato because of their higher harvesting efficiency and less of both losses and cost comparing with the chisel plow. 

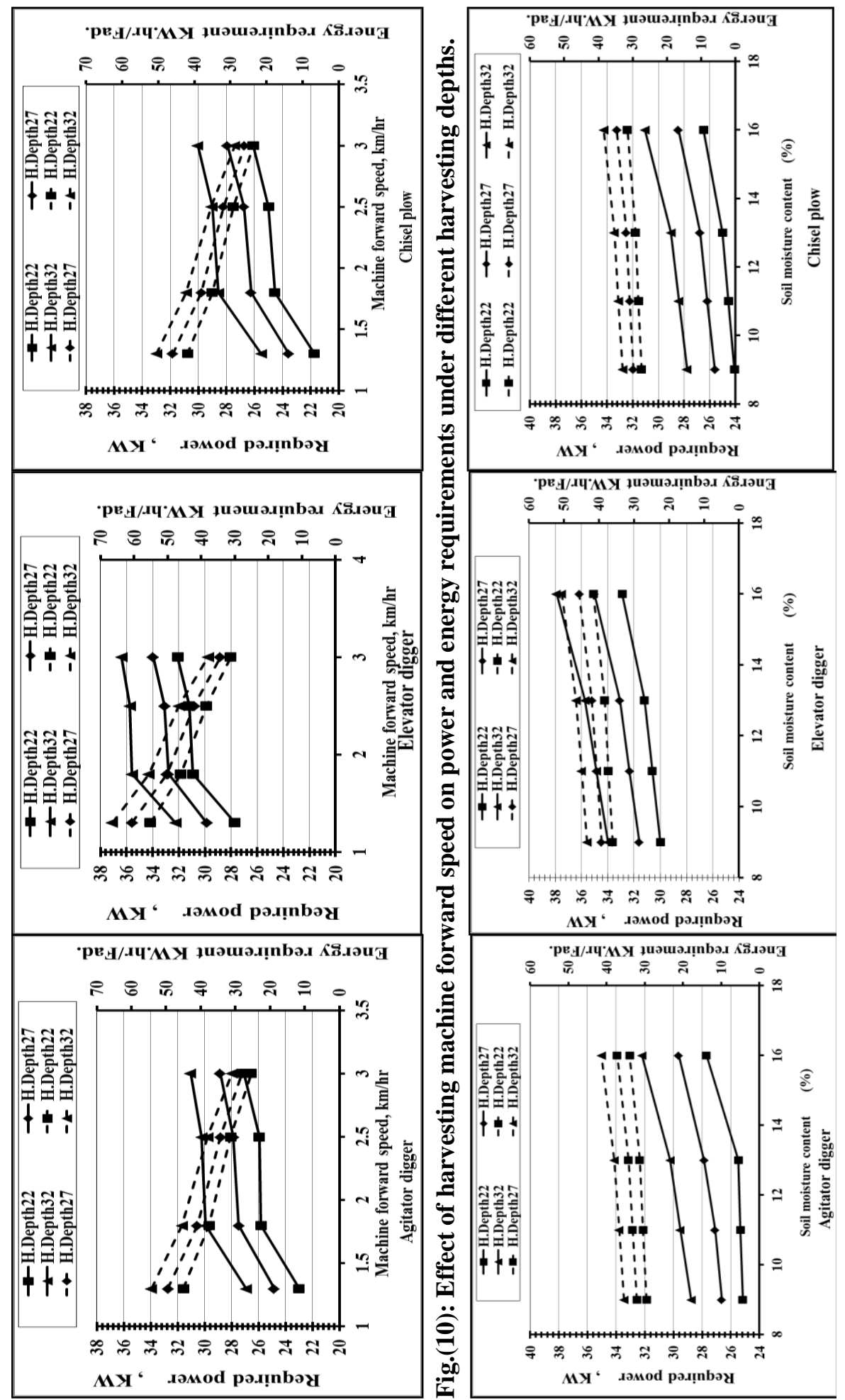

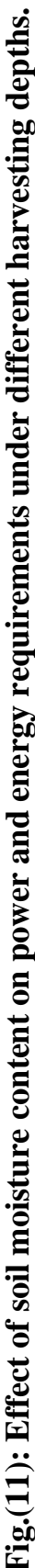



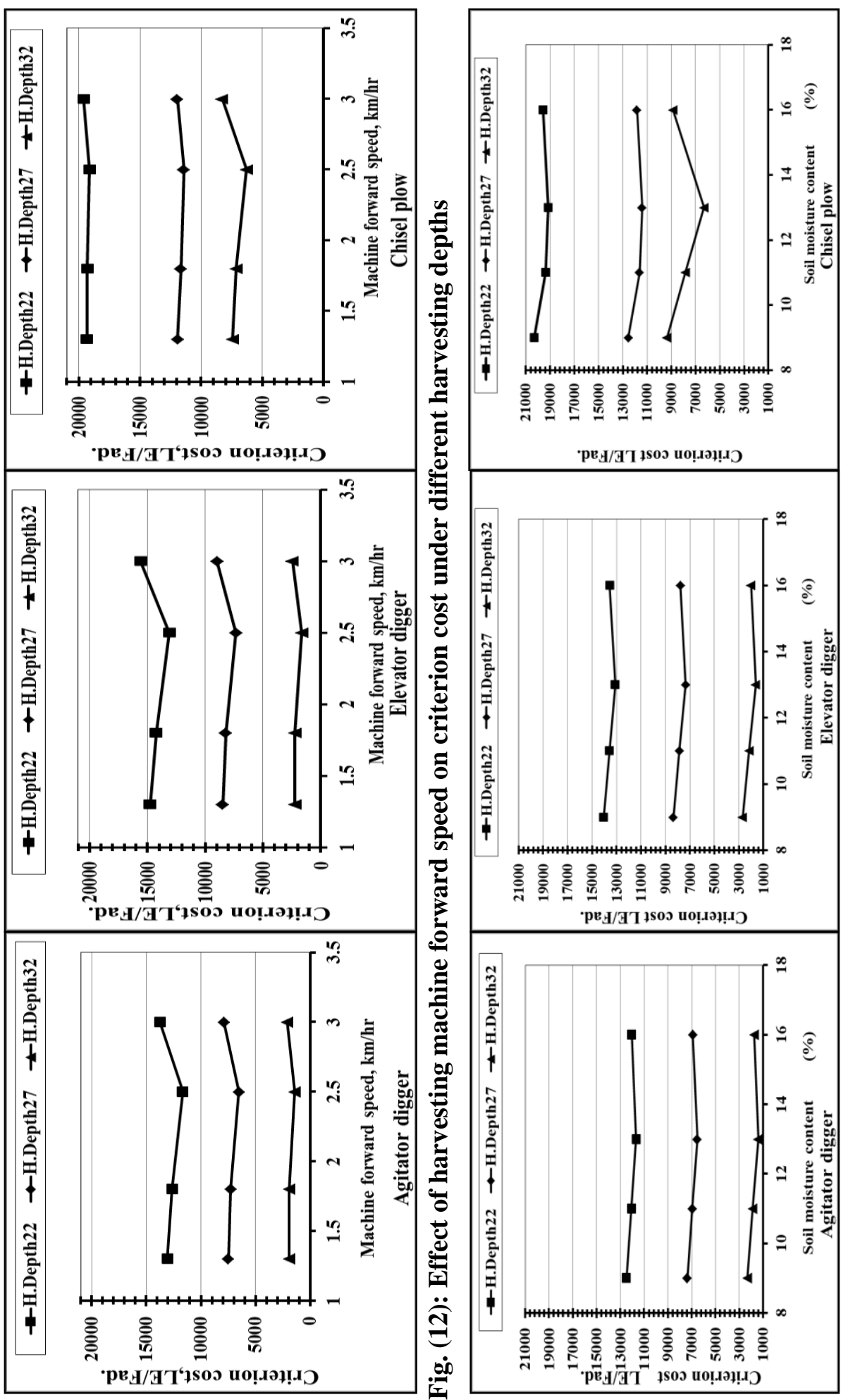

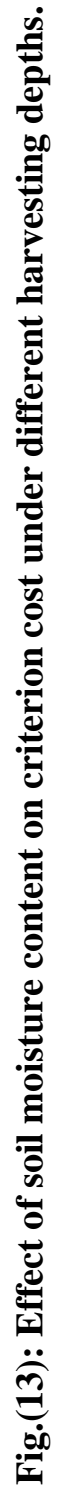


2. The proper operational conditions for operating the potato digger are: forward speed of $2.5 \mathrm{~km} / \mathrm{h}$, harvesting depth of $32 \mathrm{~cm}$, and soil moisture content of $13 \%$.

\section{REFERENCES}

Abdel Maksoud, S.E., M.M. Morad and H.A. Morghany (2004). Development of a combination unit for harvesting and gathering potatoes crop. Ph. D. Thesis, Agric. Eng. Dept., Fac. Agric., Zagazig Univ.

Abdel-Aal, S.E., M. S. El-Shal, M.K. Abdel-Wahab and A.A. AbdelBary (2002). Development of a potato harvester suitable for Egyptian farms. Misr J. Agric. Eng., 19 (3): 643-656.

Afify, M.K. and W.M. Mechail (2000). Development of a simple potato harvester. Misr J. Agric. Eng., 17 (3): 589-604.

Ali, M.M. (2013). Manufacture and evaluation of digger of a local simplified potato digger. Misr J. Agric. Eng., 30 (1):139-158.

Amin, A. (1990). Mechanization for potato production on small farms. Ph. D. Thesis, Fac. Agric., Mansoura Univ., Egypt.

Arfa, G.K. (2007). The effect of harvesting operation on potato crop handling. Misr J. Agric. Eng., 24 (3): 492-503.

Awady, M.N. (1978). Tractor and Farm Machinery. Text book, Fac. Agric., Ain-Shams Univ., 164-167.

Awady, M.N., E.Y. Ghoneim and A.I. Hashish (1982). A Critical Comparison Between Wheat Combine Harvester Under Egyptian Conditions. R.S. No. 1920, Ain-Shams Univ.

Barger, E., B.L. Eohl, W.M. Carleton and E.G. Mckibben (1963). Tractor and their power units. $2^{\text {nd }}$ Ed. Wiley Sons. Mc., New York U.S.A.

Ibrahim, M.M., E. Amin and A. Farage (2008). Developing a multi purpose digger for harvesting root crops. Misr J. Agric. Eng., 25 (4): $1225-1239$.

Mady, M.A. (1999). Mechanical harvesting of sweet potatoes. Misr J. Agric. Eng., 16 (3): 460-478.

Ministry of Agriculture, Egypt (2009, 2013). Annual Statistical Bulletin of Crop Areas and Production Plant. 
Tawfik, M.A. and Y.S. Abdallah (2012). Fabricating a prototype of potato digger to suit small holdings. Misr J. Agric. Eng., 29 (2): 705 $-724$

Younis, S.M. (1987). Mechanization of potato harvesting with minimum losses. Alex. J. Agric. Res., Egypt, 32 (3): 1-10.

Younis, S.M., M.I. Ghonimy and T.H. Mohamed (2006). Developed of potato digger. Misr J. Agric. Eng., 23(2):292-313.

\section{الملخص العربي}

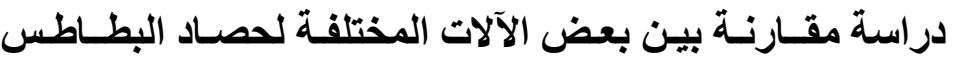

في الحيـازات الصغيرة

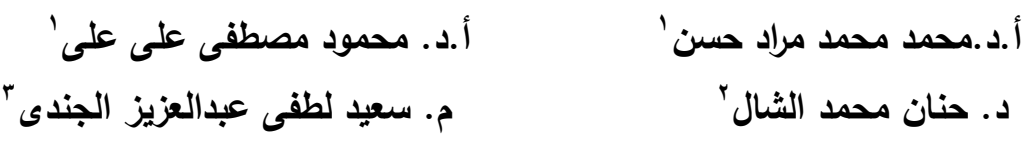

تم إجر اء التجربة فى مشروع الثباب بمحافظة الإسماعيلية للمقارنة بين ثلاث أنواع من آلات

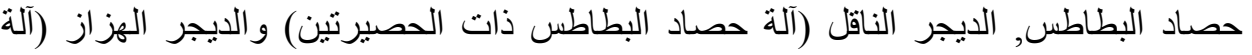

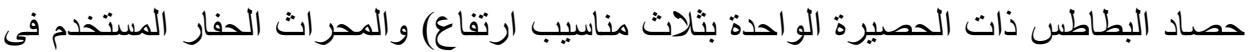

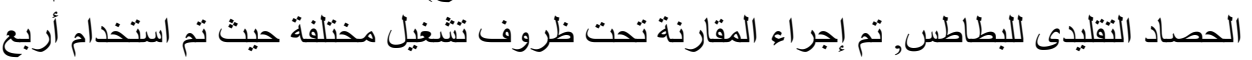

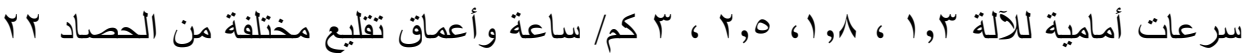

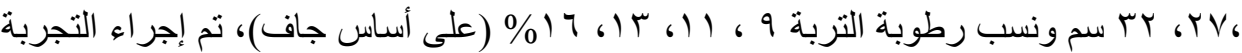

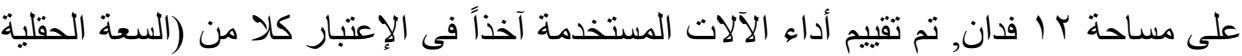

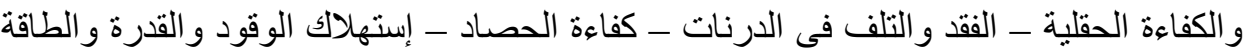

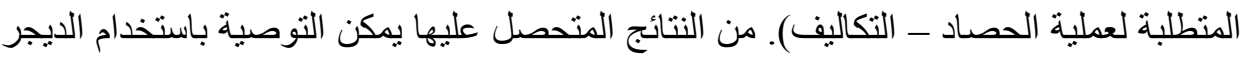

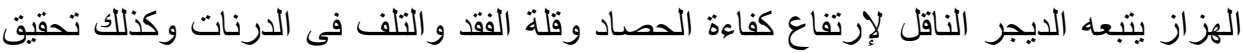

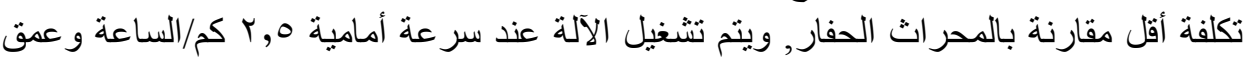

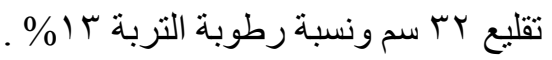

\footnotetext{
' أستاذ الهندسة الزراعية _ كلية الزراعة ـ جامعة الزقازيق- مصر.

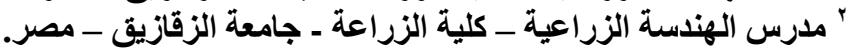

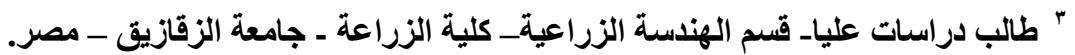

